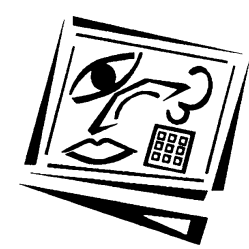

\title{
Online learning communities: Investigating a design framework
}

\author{
Chris Brook and Ron Oliver \\ Edith Cowan University
}

This paper reports the development of a design framework intended to support and guide online instructors in the development of a learning community. The study was guided by an investigation of contemporary literature focused on the community construct, online learning community development and the collaborative construction of knowledge and the practices of experienced professionals working in the field. The intended outcome is a design framework that may be useful in guiding instructors in the development of said communities.

\section{Introduction}

It has been suggested that the social phenomenon of community may be put to good use in the support of online learning (Bonk \& Wisher, 2000; Hiltz, 1998; Palloff \& Pratt, 1999; Rovai, 2002). This suggestion is well supported by theories of learning that highlight the role of social interaction in the construction of knowledge (Kearsley, n.d.; Dewey, 1929; Kafai \& Resnick, 1996; Vygotsky, 1978) and those proposing that knowledge is constructed within the social milieu (Cunningham, 1996). Further support may be found in contemporary literature that reports the benefits of collaborative learning, including increased motivation (Slavin, 1990), promoting learning achievement (Johnson, 1991; Maxwell, 1998) and perception of skill development, including satisfaction (BenbunanFich, 1997). Numerous benefits associated with collaborative learning spanning the academic, social and psychological domains have been identified (Panitz, 1997). While some researchers believe that the development of learning communities should be a primary goal for online instructors (Hiltz, 1998; Palloff \& Pratt, 1999), there is little empirical evidence to guide instructors in the development process (Bonk \& Wisher, 2000; Palloff \& Pratt, 1999; Paulsen, 1995). Current guidance tends to be based on anecdotal evidence gleaned form the experience of professionals working in the area, with a notable absence of empirical studies (Bonk \& Wisher, 2000; Palloff \& Pratt, 1999). 
This paper describes an investigation of the development of online learning communities. It seeks to establish a common understanding of the term community and identify the chain of events that lead to community development and the collaborative construction of knowledge, and it proposes a model describing this sequence. Guidance was taken from contemporary literature, the practices of experienced professionals working in the field, and the experiences of students.

\section{Understanding community}

While the use of the term community is becoming increasingly common in education circles, it is important to acknowledge that a definitive definition of the term remains elusive (Puddifoot, 1996), with numerous definitions identified (Hillery, 1964). Many disciplines study the social phenomenon of community, presenting a range of understandings and making the identification of a single definition unlikely (Goth, 1992).

Notwithstanding the continued debate, several features of community have general acceptance. Communities provide systems and processes for meeting the basic human needs for survival, nurturance, socialisation and support, cosmological or ideological perspectives, a cohesive context from which a sense of identity, belonging, meaning and purpose can develop (Redfield, 1960). The community experience is central to the lives of all individuals and it is generally acknowledged that 'if the sense of living in, belonging to, and having some commitment to, a particular community is threatened then the prospect of living rewarding lives is diminished' (Puddifoot, 1996 p. 327). The experience within a community is context specific and may vary between members (Sonn, Bishop, \& Drew, 1999). Communities exist in both a geographic and relational sense (Gusfield, 1975; Worsley, 1991), with modern societies tending to develop more relational communities (Durkheim, 1964; Royal \& Rossi, 1996) or communities of the mind (Tönnies, 1974). It is these communities that form in the online environment (Obst, Zinkiewicz, \& Smith, 2002; Surratt, 1998).

Communities take many forms including those based in religion, politics and neighborhoods (Goth, 1992; Sarason, 1974). Of the various forms of community, a learning community is characterised by a willingness of members to share resources, accept and encourage new membership, regular communication, systematic problem solving and a preparedness to share success (Moore \& Brooks, 2000). These characteristics clearly represent factors that may be put to good use in the support of learning, as does the social phenomenon where the sum of the parts of a community is in some way greater than the whole (Hawley, 1950). 
Although these characteristics tend to suggest a positivistic view of community, it is important to acknowledge that the social phenomenon may exert negative influences on members. Potentially negative influences include the need for members to conform and the subsequent loss of individuality (Wiesenfeld, 1996), and the potential to hoard knowledge and thus restrict innovation (Wenger, McDermott, \& Snyder, 2002). Also noteworthy is the potential for community structures to exert pressure on some individuals to engage in nonconforming rather than conforming behaviours, resulting in dissidents and the formation of sub-communities (Carol, 1997). Although possibly undesirable, the potential for the development of the characteristics cannot be ignored when the social phenomenon of community is employed to enhance learning experiences.

Identifying general agreement on key features of community is a useful exercise in ensuring commonality of meaning and establishing characteristics of the desired product, but does little to further insight into how a community may be purposefully developed. To achieve this requires further investigation of the community construct, how this construct may be understood and measured, and the chain of events that are likely to lead to its development.

\section{The sense of community}

The community construct is widely accepted as a sense rather than a tangible entity (Wiesenfeld, 1996). This sense may have many referents, ranging from sporting groups to neighborhoods, and simultaneous membership to multiple communities is possible and indeed likely, although not all will give a positive sense of community (Sarason, 1974). Sense of community is based on an attachment relationship, and this relationship is not based on the interactions with any one member of the community, but instead with any member (Hill, 1996). Sense of community has been defined as 'a sense that members have a belonging, members matter to one another and to the group and a shared faith that member's needs will be met through their commitment to be together' (McMillan \& Chavis, 1986p. 9). While this is not accepted as the definitive definition of community it is accepted as a good fit (Sarason, 1974) and has been adopted for the purpose of this study.

McMillan and Chavis (1986) proposed that sense of community may be represented as a four dimensional model comprising the elements of membership, influence, fulfillment of needs and shared emotional connection, with each of the elements characterised by key attributes (Table 1). 
Table 1: Elements of sense of community

\begin{tabular}{|l|l|}
\hline Element & Attribute \\
\hline Membership & $\begin{array}{l}\text { Boundaries that separate us from them } \\
\text { Emotional safety } \\
\text { A sense of belonging and identification } \\
\text { A common symbol system }\end{array}$ \\
\hline Influence & $\begin{array}{l}\text { Individual members matter to the group } \\
\text { The group matters to the individual } \\
\text { Making a difference to the group } \\
\text { Individual members influence the group } \\
\text { The group influences the individual member }\end{array}$ \\
\hline $\begin{array}{l}\text { Fulfillment of } \\
\text { needs }\end{array}$ & $\begin{array}{l}\text { Benefits and rewards } \\
\text { Members meeting their own needs } \\
\text { Members meeting the needs of others } \\
\text { Reinforcement and fulfillment of needs }\end{array}$ \\
\hline $\begin{array}{l}\text { Shared } \\
\text { emotional } \\
\text { connection }\end{array}$ & $\begin{array}{l}\text { Identifying with a shared event, history, time, place or experience } \\
\text { Regular and meaningful contact } \\
\text { Closure to events } \\
\text { Personal investment } \\
\text { Honour } \\
\text { Spiritual connection }\end{array}$ \\
\hline
\end{tabular}

These elements and their attributes may prove useful in guiding the development of online learning communities, keeping in mind the varying presence of each element in any given community, and that shared emotional connection is considered the definitive element of true community (McMillan, 1996). Promoting these elements through a common symbol system (McMillan \& Chavis, 1986; Palloff \& Pratt, 1999), establishing a common purpose (Hawley, 1950), facilitating frequent and easy meetings (Worsley, 1991) and developing a sense of place (Lorion \& Newbrough, 1996; Puddifoot, 1996) is likely to influence community development. In addition it has been suggested that sense of community be considered an economy where self disclosure is the commodity for trade. In this environment trade must be perceived as fair (McMillan, 1996) and as safe (McLellan, 1998), free from shame, where individuals may trade freely.

Guidance for developing this safe environment may be found in the literature that suggests encouraging low risk trade, where individuals identify similarities, provide positive support and share information (McMillan, 1996). Once this has been established it is possible to progress to activities that require identifying differences including strengths, weakness and needs. It is not until this has been achieved that members can begin trade and the community economy is established (McMillan, 1996). The sequential five stage model developed by Salmon (2000) which includes access and motivation, online socialisation, information exchange, 
knowledge construction and development supports this supposition. Further guidance may be gleaned from the experiences of professionals working in the area.

\section{The role of communities in the learning process}

There exists debate among theorists as to the role that communities play in the learning process. The cognitive theories of learning, which have become influential in educational environments in relatively recent times, investigate the internal process that takes place to facilitate learning. In general terms, cognitive psychologists see the learner as an active participant in the learning process, actively constructing new knowledge based on current and past experiences (Kafai \& Resnick, 1996). This field of thought is known as constructivism. Perhaps the most widely regarded theorist in this area is Jean Piaget who proposed that mental growth is governed by continual activity aimed at balancing the intrusions of the social and physical environment with the organism's need to preserve its structural systems (Elkind, 1967). Piaget proposed that intellectual growth is a result of four contributing factors, maturation, physical experience, social experience and equilibration (Elkind, 1967).

A second perspective of learning within the cognitive domain is the sociocultural theory that works in contrast to the constructivist view. Where the constructivist perspective focuses on individual cognitive processes in the construction of knowledge, the sociocultural perspective emphasises the role of social interactions and cultural organised activities in influencing cognitive development (Cobb, 1994). Two influential theorists who advocate the importance of social interaction in the construction of knowledge are Vygotsky and Dewey (Glassman, 2001). While Vygotsky emphasises the importance of social history, Dewey stresses the importance of individual history (Glassman, 2001). Vygotsky places a heavy emphasis on the role of culture and social history in education, suggesting that the process of education works from the outside in. Dewey, with a heavy emphasis on the importance of the social history of the individual, sees the process as coming from the inside out (Glassman, 2001). Notwithstanding this philosophical difference, both theorists stress the importance of social interaction in the learning process.

Cobb (1994) argues that the cognitive and sociocultural theories are complementary. The sociocultural perspective suggests the conditions for the possibility of learning, while constructivist perspective outlines what students learn and the process by which they learn (Cobb, 1994).

This suggestion is reflected in a third field of thought known as constructionism. Constructionism includes the theories espoused by Piaget, but goes beyond these to include the notion that the process of learning 
takes place when the learner is engaged with the construction of something external. This leads to a cycle of internalising what is outside and then externalising what is inside, and so on (Papert, 1990). Constructionism is seen as offering an important bridge between cognitive and sociocultural perspectives on cognitive development, by arguing that individual development cycles are enhanced by shared constructive activity in the social environment. Furthermore, social settings are enhanced by the cognitive development of the individual. The constructionist view is that shared constructions and social relations are key to individual development (Kafai \& Resnick, 1996).

Importantly it is suggested that settings marked by fractured and limited social activity and less cohesive social relations may present troubling development barriers (Kafai \& Resnick, 1996), supporting the supposition that sense of community may be put to good use in the support of learning.

\section{The construction of knowledge in communities}

Similar to community, the term knowledge is commonly used, yet surprisingly complex. At times the term is used to refer to tangible objects that can be captured, codified and stored, known as structured knowledge. At other times the term is used to refer to the human element of knowledge that cannot be articulated, codified, captured or stored, known as less structured knowledge (Hildreth \& Kimbe, 2002). Other terms include formal and informal knowledge, used to separate knowledge that can be bound in books and shared, from the knowledge that is used to create that which is bound in books and shared (Conklin, 1996). Hildreth (2002) suggested that of the many terms that are used to describe knowledge, the most controversial distinction of all is made between tacit knowledge (that which cannot be told) (Polanyi, 1967) and explicit knowledge (that which is easily expressed) (Nonaka, 1991). Despite the varying views and the continued debate, there appears to be general agreement that at some level knowledge can be viewed as comprising both external and human elements.

While stressing the importance of the social construction of knowledge (Dewey, 1929; Von Krogh, 1998; Vygotsky, 1978), Hildreth (2002) maintains that the tacit and explicit elements of knowledge are interwoven. Attempts to advance the construction of knowledge must focus on both these elements of knowledge, moving away from capturing to sharing knowledge (Hildreth \& Kimbe, 2002), in accordance with constructivist philosophies (Von Krogh, 1998). Researchers argue that this 
sharing of knowledge is promoted in both communities of practice (Wenger, 1998) and learning communities (Moore \& Brooks, 2000).

It has been suggested that the social construction of knowledge in the online environment progresses through five sequential phases (Gunawardena, Lowe \& Anderson, 1997) (Table 2).

Table 2: Interactive analysis model for examining social construction of knowledge in computer conferencing

\begin{tabular}{|l|}
\hline Five phase model \\
\hline Sharing and comparing of information \\
\hline $\begin{array}{l}\text { The discovery of exploration of dissonance or inconsistency among ideas, } \\
\text { concepts or statements }\end{array}$ \\
\hline The negotiation of meaning \\
\hline Testing and modification of proposed synthesis or co-construction \\
\hline Agreement statements and the application of newly constructed meaning \\
\hline
\end{tabular}

Statements of opinion and observation and corroborating examples provided by one or more participants characterise phase one. Phase two identifies and states areas of disagreement, and perhaps escalates conflict through reference to research or experience. Exploration of meaning and the identifying of areas of agreement characterise phase three, and phase four is characterised by testing the proposed synthesis against 'received fact', as shared by the participants and or their culture. Metacognitive statements by the participants, illustrating their understanding that their new knowledge or ways of thinking have changed, characterise phase five (Gunawardena et al., 1997). The latter stages of the model require high levels of bi-directional influence between the individual and the group, an identifying characteristic of strong communities (McMillan, 1996). Of particular interest is how student interactions may be purposefully progressed through these phases, to both promote the collaborative construction of knowledge and the formation of a strong community.

\section{Developing online learning communities}

It appears that the decision to pursue or ignore membership in a community rests with the will of the individual. Will has been categorised as either rational or natural will (Tönnies, 1955). While natural will refers to more personal characteristics and traits such as character, intellect and attitude, rational will refers to a rational decision making process. An individual's natural will may suggest a positive or negative predisposition to community orientation, while rational will suggests a more pragmatic attitude toward community membership, heavily influenced by purpose and perceived benefits. It has been demonstrated that individuals may 
exercise rational will to seek community membership, even when antipathy is the norm (Tönnies, 1955). This suggests it is possible for online instructors to employ forms of engagement and activity that may influence an individual's rational will to seek community membership, in the event that natural will is predisposed to ignore the possibility. For this to take place, there is a need for consistency between the underlying philosophy of learning and the structure of the learning environment, including tasks and activities (Bonk \& Cunningham, 1998). Simply employing the software and hoping that conditions conducive to the formation of community will develop is unlikely to result in community development, as has been identified by Hiltz (1997), who asserts:

The development of a collaborative learning environment is not simply a matter of employing the software to facilitate a communication place and informing the students of its availability and telling them to use it at will. This will result in students not using the communication opportunity at all or dropping out of communication after a very short time (p. 2).

Factors that may influence community development include policies (Cho \& Berge, 2002), the discipline and educational level of the course (Hiltz, 1994; Palloff \& Pratt, 1999), the instructor (Collins \& Berge, 1996; Hiltz, 1994; Palloff \& Pratt, 1999) and the students (Hiltz, 1994). At a process level, influencing factors include the purpose the community serves in the lives of its members (Hawley, 1950; Palloff \& Pratt, 1999), support for communication (Collins \& Berge, 1996; Hill \& Raven, 2000), the nature of meetings (Moore \& Brooks, 2000) and the gathering place (Lorion \& Newbrough, 1996; Palloff \& Pratt, 1999; Puddifoot, 1996; Von Krogh, Ichijo, \& Nonaka, 2000). These factors are outlined in more detail in the following paragraphs.

This suggests influencing factors and a chain of events that may be expressed by adapting the three 'P' model of presage, process and product (Biggs, 1989). The Biggs (1989) model describes the process of student learning and may be used to inform approaches to teaching. As described by the model, presage factors at both the student and teacher level interact to produce an approach to learning. Process factors describe the approaches students adopt to process academic tasks, and the product reflects the learning outcome (Biggs, 1989). Community development may be described in a similar manner, beginning with presage factors, including the system, learning context and student, that interact to produce an approach to community development. These progress to process factors that describe how students process community development strategies, facilitating and concluding with, among other products, sense of community as an outcome. (Figure 1) 


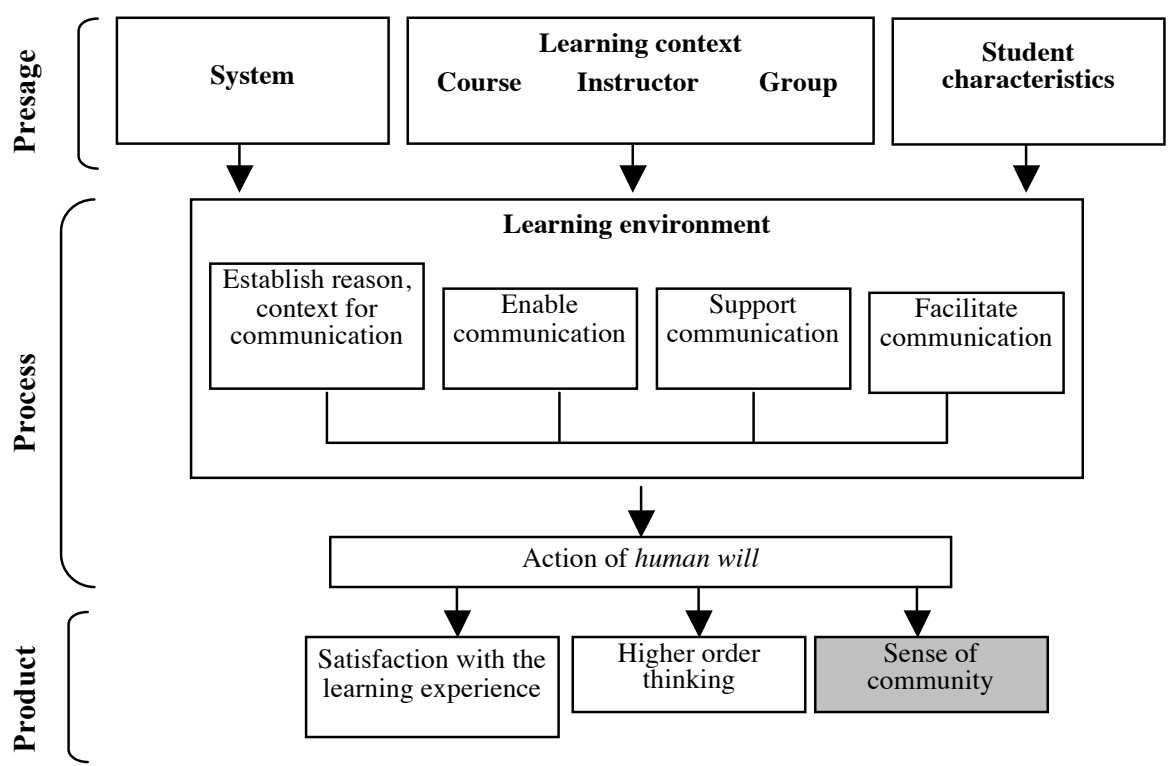

Figure 1: Presage, Process and Product in learning environments supporting community development

The framework presents an integrated system representing factors that exist prior to the process of community development, the approaches supporting community development, the process of community development, and a myriad of outcomes, including sense of community.

\section{Presage}

Presage factors are presented in three categories of system, learning context and student characteristics. System factors refer to factors at the institutional level and include online policies and support, learning management systems and grading policies. The learning context is broken into three sections referring to factors at the course level, including academic level, subject orientation and discipline factors, at the instructor level including experience, education philosophy and self identity, and group factors including cohort size. Those at the student level refer, among other factors, to educational level, learning style and perception of self. 


\section{System factors}

Contemporary literature suggests that providing teachers and students with appropriate access to technology and appropriate support promotes community development (Berge, L, \& Haneghan, 2002; Collins \& Berge, 1996; Hill \& Raven, 2000; Palloff \& Pratt, 1999; Salmon, 2000). Online learning environments having poor access and support as the norm tend to be characterised by low levels of participation, an identified requirement for the development of sense of community (Brook \& Oliver, 2002). Avoiding competition for a limited resource is also an important consideration. Environments that are characterised by high levels of competition for limited resources tend to be dominated by able members who exclude the weak (Hawley, 1950). This is sometimes reflected in system wide grading policies that restrict the number of high grades available to the cohort, thereby ensuring competition for a limited and desired resource.

\section{Course factors}

Factors at the course level include the educational level and discipline of study (Hiltz, 1994; Palloff \& Pratt, 1999). Courses designed for the undergraduate level tend to require more structure and higher levels of instructor participation than those designed for the postgraduate level (Hiltz, 1994). In addition, some disciplines of study are more conducive to both the online environment and strategies that promote community development (Hiltz, 1994). Outcomes and objectives in course design are also influencing factors, as are the course syllabus and structure (Palloff \& Pratt, 1999).

\section{Instructor factors}

It has been suggested that the role of the instructor is pivotal in the development of online learning communities (Collins \& Berge, 1996; Hiltz, 1998; Palloff \& Pratt, 1999). The manner in which this role is approached depends on the characteristics and beliefs of the instructor (Lounsbury \& DeNeui, 1996), including educational philosophies (Collins \& Berge, 1996; Hiltz, 1998; Palloff \& Pratt, 1999; Paulsen, 1995), perceptions of self as either connected or separate (Gilligan, 1982) and perceptions of their role. Other considerations include the instructor's online experience, the nature of the social environment they develop, and the manner in which they manage the learning environment (Collins \& Berge, 1996; Palloff \& Pratt, 1999). 


\section{Group factors}

The nature of the cohort, including the number of participants, may also influence community development strategies. In asynchronous environments, group size is recommended to be no larger than 25, while 10 is suggested for the synchronous environment (Palloff \& Pratt, 1999). The impact of individual characteristics and personality traits on the development of sense of community is likely to be reflected in the collective group. Groups that are dominated by individuals who perceive themselves as separate are likely to be characterised by competition, while those dominated by connected individuals are likely to be characterised by cooperation (Gilligan, 1982).

\section{Student characteristics}

While formulating forms of engagement and activity to promote community development and encourage student participation may fall to the instructor (Hiltz, 1998; Palloff \& Pratt, 1999), the student is not (and cannot be) a passive observer (Hiltz, 1994). The role and responsibility of the student is to be an active participant in both the learning and community experience (Palloff \& Pratt, 1999). The characteristics of participating students are likely to impact on both participation in the learning experience, and the development of sense of community (Lounsbury \& DeNeui, 1996). Influencing factors include the level of education and online experience (Hiltz, 1997), perceptions of self as either connected to or separate from others (Gilligan, 1982), and approaches to communication based on a need for connection or status (Gougeon, 2002). Patterns of socialisation, which tend to be gender based (Belenky, Clinchy, Golberger, \& Tarule, 1986; Tannen, 1990, 1994, 1995), are also likely to impact on community development. It is suggested that students adopting the socialised female role are more likely to seek membership in learning communities than their socialised male counterparts. Culture, which governs underlying beliefs, values and how we communicate and act among people, is also likely to impact on the development of sense of community (Triandis, 1996). (Table 3)

\section{Process factors}

While presage factors exist prior to any direct attempt by the instructor to establish community, process factors describe the forms of engagement and activity purposefully employed by the instructor to facilitate community development and the manner in which students respond. Process factors are presented in four categories of reason and context for communication, enabling communication, supporting communication and facilitating communication, with each of these categories comprising factors outlined in more detail in the following paragraphs. 
Table 3: Presage factors influencing community development in online settings

\begin{tabular}{|c|c|c|c|c|}
\hline \multirow[t]{2}{*}{ System } & \multicolumn{3}{|c|}{ Learning Context } & \multirow[t]{2}{*}{ Student } \\
\hline & Course & Instructor & Group & \\
\hline $\begin{array}{l}\text { - Accessibility } \\
\text { policy } \\
\text { - Online policy } \\
\text { and support } \\
\text { - Grading } \\
\text { policy } \\
\text { - Technical } \\
\text { support } \\
\text { - Cohort } \\
\text { selection } \\
\text { criteria } \\
\text { - Teaching } \\
\text { focus } \\
\text { - Funding }\end{array}$ & $\begin{array}{l}\text { - Orientation - } \\
\text { discipline } \\
\text { - Academic } \\
\text { level } \\
\text { - Elective or } \\
\text { core } \\
\text { - Subject } \\
\text { material } \\
\text { - Cohort size } \\
\text { - Cultural and } \\
\text { gender mix }\end{array}$ & $\begin{array}{l}\text { - Experience } \\
\text { (teaching } \\
\text { online) } \\
\text { - Educational } \\
\text { philosophy } \\
\text { - Cultural } \\
\text { Patterns of } \\
\text { socialisation } \\
\text { - Perceptions } \\
\text { of self } \\
\text { identify } \\
\text { - Management } \\
\text { style }\end{array}$ & $\begin{array}{l}\text { - Collective } \\
\text { character- } \\
\text { istics } \\
\text { - Cohort size }\end{array}$ & $\begin{array}{l}\text { - Education } \\
\text { level } \\
\text { - Experience } \\
\text { (learning } \\
\text { online) } \\
\text { - Learning } \\
\text { style } \\
\text { - Patterns of } \\
\text { socialisation } \\
\text { - Cultural } \\
\text { identity } \\
\text { - Access to } \\
\text { technology } \\
\text { - Goals } \\
\text { - Motivation } \\
\text { - Personality } \\
\text { traits } \\
\text { - Perceptions } \\
\text { of self }\end{array}$ \\
\hline
\end{tabular}

\section{Reason and context}

Essential in the formation of all communities is the purpose that the community serves in the lives of its members (Hawley, 1950; Sarason, 1974). This purpose may be based in the resolution of a common problem or attainment of a common goal (McMillan, 1996; Tönnies, 1955; Worsley, 1991). Purpose may also rest with perceived benefits received for membership (Lott \& Lott, 1965; McMillan, 1996), which may include an increase in both intellectual (Stewart, 1997) and social capital (Putnam, 2000), or unspecified individualised benefits (McMillan, 1996). It has been suggested that a significant purpose may be instrumental in the formation of communities in circumstances where antipathy is the norm (Tönnies, 1955). While it is not practical (and perhaps not possible) to identify what will constitute a significant purpose for all participants (McMillan, 1996), it is possible to establish purpose at multiple levels, in an attempt to attract members with variable needs. Purpose may reflect the manner in which student participation is encouraged. Suggestions include mandated participation through the allocation of grades (Hiltz, 1998; Palloff \& Pratt, 1999), providing an increase in intellectual resources through guest experts (Hiltz, 1994), presenting a problem or disorientating dilemma (Moore \& Brooks, 2000), and linking activities to the lived in world (Palloff \& Pratt, 1999). Further support may be attained through setting complex ill- 
defined problems that reflect authentic activities (Herrington \& Oliver, 1995), or providing a disorientating dilemma or a controversial issue (Moore \& Brooks 2000), or presenting an onerous workload (Brook \& Oliver, 2003). The purpose and context may also be established through encouraging the collaborative construction of knowledge (e.g. Gunawardena et. al, 1997), facilitated through group work or projects (Brook \& Oliver, 2002), or by the instructor acting as an agent provocateur (Hiltz, 1998). It is also possible to stimulate purpose and context through actively promoting social activities (Palloff \& Pratt, 1999; Hiltz, 1998; Hill, 2000) (Table 4).

Table 4: Establish reason and context to promote community development

\begin{tabular}{|c|c|c|c|}
\hline $\begin{array}{l}\text { Problem solving or } \\
\text { task completion }\end{array}$ & $\begin{array}{c}\text { Product } \\
\text { development }\end{array}$ & $\begin{array}{c}\text { Knowledge sharing - } \\
\text { construction }\end{array}$ & Social activity \\
\hline $\begin{array}{l}\text { - Present a } \\
\text { disorienting } \\
\text { dilemma } \\
\text { - Present complex and } \\
\text { authentic } \\
\text { problems / tasks } \\
\text { - Present controversial } \\
\text { issues } \\
\text { - Present an onerous } \\
\text { workload } \\
\text { - Grade participation }\end{array}$ & $\begin{array}{l}\text { - Develop an } \\
\text { artifact } \\
\text { - Develop a } \\
\text { plan }\end{array}$ & $\begin{array}{l}\text { - Access to expert } \\
\text { opinion } \\
\text { - Agent provocateur } \\
\text { - Debate conflicting } \\
\text { views } \\
\text { - Group work - } \\
\text { projects } \\
\text { - Encourage conflict of } \\
\text { schema and } \\
\text { knowledge } \\
\text { construction }\end{array}$ & $\begin{array}{l}\text { - Increased } \\
\text { social capital } \\
\text { - Coffee shop } \\
\text { - Pub } \\
\text { - Water cooler } \\
\text { - Student } \\
\text { initiated } \\
\text { - Instructor } \\
\text { initiated }\end{array}$ \\
\hline
\end{tabular}

\section{Enable communication}

An essential requirement for community development is regular and meaningful meetings (McMillan, 1996; Moore \& Brooks, 2000; Tönnies, 1955). In the online environment, these meeting may be facilitated through technology tools such as discussion boards, chat facilities, email or instant messaging (Isenhour, Carroll, Neale, Rosson, \& Dunlap, 2000). It is important to remember, however, that this technology does not by necessity prevent the use of other, more traditional meeting methods, such as face to face and telephone. In essence the nature of these meetings, the meeting schedule and the manner in which participants take part will reflect the perceived purpose of participation.

Communication may be encouraged through grading participation, based on the quality or quantity of communications (Hilts, 1998; Palloff \& Pratt, 1999), requesting responses (Hiltz, 1994), establishing a sense of positive outcome as a result of belonging, and encouraging members to pay their dues (McMillan, 1996). Setting an appropriate pace and schedule for participation that maintains active engagement, without dominating the learning experience, may provide further support (Collison, Elbaum, 
Haavind, \& Tinker, 2000). Establishing the nature of communication, including the tools to be used, roles and responsibilities, enables communication (Palloff \& Pratt, 1999), as does establishing a sense of connectedness. Strategies that promote connectedness include engendering the human elements of community (Hill \& Raven, 2000) and establishing user profiles (Kim, 2000). Additional strategies include welcoming new members, sharing wisdom, resolving problems and sharing success (Moore \& Brooks, 2000). Allowing for growth and change, two characteristics of community (Sarason, 1974), also promotes a sense of connectedness and community development (Table 5).

Table 5: Enable communication to promote community development

\begin{tabular}{|c|c|c|c|}
\hline Participation & Schedule & Nature & Connectedness \\
\hline $\begin{array}{l}\text { - Required } \\
\text { - Recommended } \\
\text { - Suggested } \\
\text { - Optional } \\
\text { - Necessary } \\
\text { - As needed } \\
\text { - Request } \\
\text { responses } \\
\text { - Establish a } \\
\text { sense of } \\
\text { positive } \\
\text { outcomes - the } \\
\text { result of } \\
\text { belonging } \\
\text { - Membership } \\
\text { pay their dues }\end{array}$ & $\begin{array}{l}\text { - Establish and } \\
\text { maintain } \\
\text { appropriate } \\
\text { pace } \\
\text { - Fixed } \\
\text { meeting } \\
\text { schedule } \\
\text { - Meetings as } \\
\text { required } \\
\text { - Daily } \\
\text { meetings } \\
\text { - Weekly } \\
\text { meetings } \\
\text { - Instructor } \\
\text { initiated } \\
\text { meetings } \\
\text { - Student } \\
\text { initiated } \\
\text { meetings }\end{array}$ & $\begin{array}{l}\text { - Small group } \\
\text { - Whole class } \\
\text { - Set topics } \\
\text { - Social discussion } \\
\text { - Course issues } \\
\text { - Report presentation } \\
\text { - Student as expert } \\
\text { - General discussion } \\
\text { - Reflective } \\
\text { - Gapplication) } \\
\text { - Global (instructor to } \\
\text { all) } \\
\text { - Student initiated } \\
\text { - Instructor initiated } \\
\text { - Student to student } \\
\text { - Student to instructor } \\
\text { - Instructor to student } \\
\text { - Role play } \\
\text { - Email (available) } \\
\text { - Chat (available) } \\
\text { - Instant messaging } \\
\text { (available) } \\
\text { - Telephone (available) } \\
\text { - Face to face } \\
\text { (available) }\end{array}$ & $\begin{array}{l}\text { - Ensure all } \\
\text { participants are } \\
\text { present and active } \\
\text { - Establish user profiles } \\
\text { - Make member } \\
\text { responsibilities } \\
\text { explicit } \\
\text { - Encourage prompt } \\
\text { and timely responses } \\
\text { - Weave comments } \\
\text { - Normalise and permit } \\
\text { disagreement } \\
\text { (resolved by } \\
\text { participants) } \\
\text { - Allow for differing } \\
\text { roles } \\
\text { - Allow sub groups } \\
\text { - Welcome new } \\
\text { members } \\
\text { - Value all members } \\
\text { - Take time to think } \\
\text { and reflect } \\
\text { - Share wisdom } \\
\text { - Resolve problems } \\
\text { collectively } \\
\text { - Share success } \\
\text { - Allow growth and } \\
\text { change }\end{array}$ \\
\hline
\end{tabular}

\section{Support communication}

Supporting communication includes assisting students in becoming proficient with the technology (Berge \& Collins, 1995; Palloff \& Pratt, 1999), developing text based communication skills (Suler, 2000) and instituting a sequencing of activities (Salmon, 2000). 
Assisting students in coping with the technology includes providing support for the resolution of problems and stating the technology requirements (Palloff \& Pratt, 1999). Providing multiple means of access (Hill, 2000) also assists students to cope with technology, as does normalising problems and the appropriate use of humour (Brook \& Oliver, 2003). Given the importance of non-verbal factors in communication (Dunn, 1999), which are to a large extent absent in text based environments (Donath, n.d), helping students develop text based communication skills may also support community development (Suler, 2000). There is also a need to prepare students for the possibility of both conflict and tension (Palloff \&Pratt, 1999). Due to the more independent nature of the online learning environment, there is a need to support students in managing their own learning experience including setting goals and prioritising tasks (Hill, 2000). It is also useful to provide weekly reminders (Brook \& Oliver 2003) and clearly state roles and responsibilities (Palloff \& Pratt, 1999).

Table 6: Supporting communication

\begin{tabular}{|c|c|c|c|}
\hline Technology skills & $\begin{array}{c}\text { Communication } \\
\text { skills }\end{array}$ & Management skills & $\begin{array}{l}\text { Behaviour } \\
\text { guidelines }\end{array}$ \\
\hline $\begin{array}{l}\text { - State technology } \\
\text { requirements } \\
\text { - Provide multiple } \\
\text { means of access } \\
\text { - Provide links to } \\
\text { required } \\
\text { downloads } \\
\text { - Provide a help } \\
\text { desk } \\
\text { - Offer a face to } \\
\text { face help } \\
\text { - Provide online } \\
\text { help } \\
\text { - Encourage peer } \\
\text { support } \\
\text { - Normalise } \\
\text { problems } \\
\text { - Use humour }\end{array}$ & $\begin{array}{l}\text { - } \text { Modeling } \\
\text { - Text based } \\
\text { communication } \\
\text { strategies } \\
\text { - Express and } \\
\text { normalise } \\
\text { feelings of } \\
\text { uncertainty } \\
\text { - Prepare the } \\
\text { participants for } \\
\text { the possibility of } \\
\text { both tension and } \\
\text { conflict } \\
\text { (normalise this } \\
\text { experience) } \\
\text { - Establish identity } \\
\text { and avoid } \\
\text { anonymity }\end{array}$ & $\begin{array}{l}\text { - State expectations } \\
\text { - Provide time } \\
\text { management tips } \\
\text { - Provide tips for } \\
\text { prioritising tasks } \\
\text { - State roles and } \\
\text { responsibilities } \\
\text { - Post weekly } \\
\text { reminders }\end{array}$ & $\begin{array}{l}\text { - Establish safety } \\
\text { - Outline a code of } \\
\text { conduct based on } \\
\text { mutual respect } \\
\text { - Establish that it is } \\
\text { OK to be yourself } \\
\text { and tell the truth } \\
\text { - Introduce the } \\
\text { community } \\
\text { economy } \\
\text { - Identify } \\
\text { expectations of } \\
\text { participation in } \\
\text { community } \\
\text { activities (fair } \\
\text { trade) }\end{array}$ \\
\hline
\end{tabular}

Contemporary community literature suggests that essential requirements for the development of community include the provision of a safe environment where participants can express themselves, free from shame (McMillan, 1996). McMillan (1996) emphasises the need to develop trust through establishing structure. Members must know what they can expect from each other, what power relationships exist, and who holds power and when. Any breakdown in these structures is likely to result in anomie 
(Durkheim, 1964). Trust may be promoted through establishing a code of conduct (McMillan, 1996), avoiding anonymity (Palloff \& Pratt, 1999), and providing for the development of an electronic self (Kim, 2000; Palloff and Pratt, 1999). Striving to establish an electronic identity may also support community development (Kim, 2000), as may establishing leadership (Berge \& Collins, 1995; McMillan, 1996; Palloff \& Pratt, 1999; Paulsen, 1995). (Table 6)

\section{Facilitate communication}

'Community refers among other things to one's sense of place, its people, their interrelationships, their shared caring for one another and their sense of belonging' (Lorion \& Newbrough, 1996, p.312; Puddifoot, 1996). It is this sense of place that is required in online learning communities. Suggested strategies for developing this sense include incorporating human elements such as welcoming messages, and acknowledging members individually (Hill \& Raven, 2000; Palloff \& Pratt, 1999; Paulsen, 1995). Other suggestions include establishing member profiles, developing a common symbol system (Kim, 2000; Palloff \& Pratt, 1999), and including rituals from the lived in world (Kim, 2000; Suler, 2000). The tone that is established in this environment is also a critical factor, and a range of suggestions have been made including using a friendly, open and polite voice, being curious, analytical and informal (Collison et al., 2000). Encouraging sharing is also an essential strategy in effective facilitation. Sharing takes the form of trade in a community economy (McMillan, 1996). Trade is based on self disclosure and must be perceived as fair (McMillan, 1996), in an environment that provides an abundance of desired resources (Hawley, 1950). It is also suggested to progress trade from safe to risky (McMillan, 1996) in order to build trust and progress the group through stages of group development (Salmon, 2000) (Table 7).

Table 7: Facilitating communication

\begin{tabular}{|c|c|c|}
\hline Human elements & Tone & Sharing \\
\hline $\begin{array}{l}\text { - Welcome members individually } \\
\text { - Acknowledge the members } \\
\text { - Establish member profiles } \\
\text { - Establish identity } \\
\text { - Establish guidelines for } \\
\text { communication } \\
\text { - Allow for a range of roles } \\
\text { - Allow for the development of a } \\
\text { - Integrate rituals of community life } \\
\text { - Include social elements }\end{array}$ & $\begin{array}{l}\text { - Friendly } \\
\text { - Open } \\
\text { - Inviting } \\
\text { - Polite } \\
\text { - Neutral } \\
\text { - Humorous } \\
\text { - Imaginative } \\
\text { - Nurturing } \\
\text { - Curious } \\
\text { - Analytical } \\
\text { - Informal } \\
\text { - Whimsical }\end{array}$ & $\begin{array}{l}\text { - Knowledge is the } \\
\text { commodity for exchange } \\
\text { - Trade is based on self } \\
\text { disclosure (knowledge) } \\
\text { - Trade must be fair (defined } \\
\text { by members) } \\
\text { - Progress trade from safe to } \\
\text { risky } \\
\text { - Provide an abundance of } \\
\text { desired resources }\end{array}$ \\
\hline
\end{tabular}




\section{Summary and conclusion}

There is strong support for the supposition that the social phenomenon of community may be put to good use in the support of online learning. This is well supported by theories of learning that highlight the role of social interaction in the construction of knowledge. Some debate continues as to the role that social interaction plays in the construction of knowledge, but it appears that apparently conflicting views may be complementary in certain environments. The processes and procedures for developing such a community remain largely unknown, with much of current thinking based on the anecdotal records of professionals working in the field. Analysis of contemporary literature suggests the possibility of describing the processes and procedures for developing an online learning community as a model containing a chain of events that comprise presage, process and product factors. Presage factors outline the conditions for community development, process factors outline the strategies employed by the instructor to develop sense of community, and product factors outline the sense of community experience, among other outcomes.

While the model represents an integrated system suggesting factors critical to community development, it does not indicate the relative importance of any of the factors, nor those that may be considered essential or simply desirable. Further enquiry to develop an understanding of instructional emphasis, and how to design learning settings that promote community development, is required. This enquiry may be assisted through adopting the proposed framework to explore community development and the link between sense of community and the strength of proposed factors.

\section{References}

Belenky, M. F., Clinchy, B. M., Golberger, N. R. \& Tarule, J. M. (1986). Women's Ways of Knowing. USA: Basic Books.

Benbunan-Fich, R. (1997). Effects of Computer-Mediated Communication Systems on Learning, Performance and Satisfaction: A Comparison of Groups and Individuals Solving Ethical Case Scenarios. Unpublished Dissertation, Rutgers UniversityNJIT.

Berge, Z., \& Collins, M. (1995). Computer-mediated communications and the online classroom: An introduction. Cresskil: Hampton Press.

Berge, Z. L, Muilenburg, L. Y. \& van Haneghan, J. (2002). Barriers to distance education and training: Survey results. [viewed 12 May 2003, verified 29 Jul 2003] http:/ / www.emoderators.com/barriers/barriers2002.shtml

Biggs, J. B. (1989). Approaches to the enhancement of tertiary teaching. Higher Education Research and Development, 8(1), 7-25. 
Bonk, C. J. \& Wisher, R. A. (2000). Applying Collaborative and e-learning Tools to Military Distance Learning: A research Framework. United States Army Research Institute for the Behavioral and Social Sciences. [viewed 2 Jul 2002, verified 29 Jul 2003] http:/ / www.publicationshare.com/docs/Dist.Learn(Wisher).pdf

Bonk, C. J., \& Cunningham, D. J. (1998). Searching for learner-centred, constructivist, and sociocultural components of collaborative educational learning tools. In C. J. Bonk \& K. S. King (Eds.), Electronic Collaborators. Mahwah, New Jersey: Lawrence Erlbaum Associated, Publishers.

Brook, C. \& Oliver, R. (2002). Supporting the development of learning communities in online settings. Paper presented at the Ed-Media, Denver Colorado.

Carol, L. A. (1997). Masters of Sociological Thought: Ideas in Historical and Social Context (2nd ed.). Forth Worth, Texas: Harcourt Brace Jovanovich.

Cho, S. K. \& Berge, Z. (2002). Overcoming barriers to distance training and education. USDLA Journal, 16(1). [viewed 12 May 2003, verified 29 Jul 2003] http: / / www.usdla.org/html/journal/JAN02_issue/article01.html

Cobb, P. (1994). Where is mind? Educational Researcher, 23(7), 13-20.

Collins, M. \& Berge, Z. (1996). Facilitating interaction in computer mediated online courses. [viewed 10 May 2001, verified 29 Jul 2003] http: / / www.emoderators.com/ moderators / flcc.html

Collison, G., Elbaum, B., Haavind, S. \& Tinker, R. (2000). Facilitating Online Learning. Madison: Atwood Publishing.

Conklin, E. J. (1996). Designing organizational memory: Preserving intellectual assets in a knowledge economy. [viewed 20 Oct 2002, verified 29 Jul 2003] http: / / cognexus.org/dom.pdf

Cunningham, D. J. (1996). Time after time. In W. Spinks (Ed.), Semiotics 95 (pp. 263269). New York: Lang Publishing.

Dewey, J. (1929). The Sources of a Science of Education. New York: Liveright.

Donath, J. S. (n.d.) Body language without the body: Situating verbal cues in the virtual world. [viewed 7 Jul 2003, verified 29 Jul 2003] http: / duplox.wzberlin.de/docs/panel/judith.html

Dunn, L. J. (1999). Non verbal communication: Information conveyed through the use of body language. [viewed 7 July 2003, verified 29 Jul 2003] http: / / clearinghouse.mwsc.edu/manuscripts / 70.asp

Durkheim, E. (1964). The Division of Labor in Society. Free Press of Glencoe.

Elkind, D. (1967). Six Psychological Studies Jean Piaget. London: University of London Press Ltd.

Gilligan, C. (1982). In a different voice: Psychological theory and women's development. Cambridge: MA: Harvard University Press.

Glassman, M. (2001). Dewy and Vygotsky: Society experience and inquiry in education practice. Educational Researcher, 30(4), 3-14. 
Goth, D. D. (1992). Communities: An exploratory study of the existential and transpersonal dimensions of a psychological sense of community as found in the community building workshop. Unpublished Dissertation, Institute of Transpersonal Psychology, Menlo Park, California.

Gougeon, T. (2002). Participation in computer based curriculum. International Electronic Journal For Leadership in Learning, 6(22).

http: / / www.ucalgary.ca/ iejll/volume6/gougeon.html

Gunawardena, C. N., Lowe, C. A. \& Anderson, T. (1997). Analysis of a global online debate and the development of an interaction analysis model for examining social construction of knowledge in computer conferencing. Journal of Educational Computing Research, 17(4), 397-431.

Gusfield, J. R. (1975). The Community: A Critical Response. New York: Harper Colophon.

Hawley, A. H. (1950). Human Ecology A Theory of Community Structure. New York: The Ronald Press Company.

Herrington, J. \& Oliver, R. (1995). Critical characteristics of situated learning: Implications for the instructional design of multimedia. Proceedings ASCILITE'95, University of Melbourne. http:/ / www.ascilite.org.au/conferences/melbourne95/smtu / papers/herrington.pdf

Hildreth, P. J. \& Kimbe, C. (2002). The duality of knowledge. Information Research, $8(1)$.

Hill, J. L. (1996). Psychological Sense of community: Suggestions for Future Research. Journal of Community Psychology, 24(4), 431-437.

Hill, J. R. \& Raven, A. (2000). Online learning communities: If you build them, will they stay? Instructional Technology Forum, 10 October. [verified 29 Jul 2003] http: / /it.coe.uga.edu/itforum/paper46/ paper46.htm

Hillery, G. A. (1964). Villages, cities, and total institutions. American Sociological Review, 28, 32-42.

Hiltz, S. R. (1994). Online communities: A case study of the office of the future. Norwood, New Jersey: Ablex Publishing Corporation.

Hiltz, S. R. (1997). Impacts of college level courses via asynchronous learning networks: Some preliminary results. Journal of Asynchronous Learning Networks, 1(2). [verified 29 Jul 2003]

http:/ / www.aln.org/publications/jaln/v1n2/v1n2_hiltz.asp [also at http: / / eies.njit.edu / hiltz / workingpapers / philly / philly.htm]

Hiltz, S. R. (1998). Collaborative learning in asynchronous learning environments: Building learning communities. Paper presented at the WebNet 98 World Conference of the WWW, Internet and Intranet Proceedings, Orlando, Florida.

Isenhour, P. L., Carroll, J. M., Neale, D. C., Rosson, M. B. \& Dunlap, D. R. (2000). The virtual school: An integrated collaborative environment for the classroom. Educational Technology \& Society, 3(3). [viewed 25 Apr 2002, verified 29 Jul 2003] http: / /ifets.ieee.org/periodical/vol_3_2000/a03.html 
Johnson, W. D. (1991). Student-student interaction: The neglected variable in education. Educational Research, 10(1), 5-10.

Kafai, Y. \& Resnick, M. (1996). Constructionism in Practice. Mahwah, New Jersey: Lawrence Erlbaum Associates.

Kearsley, G. (n.d.). Constructivist Theory (J. Bruner). [viewed 10 May 2001, verified 29 Jul 2003] http: / tip.psychology.org/bruner.html

Kim, A. J. (2000). Community Building on the Web. Berkeley: Peachpit Press.

Lorion, R. P., \& Newbrough, J. R. (1996). Psychological sense of community: The pursuit of a field's spirit. Journal of Community Psychology, 24(4), 311-314.

Lott, A. J. \& Lott, B. E. (1965). Group cohesiveness as interpersonal attraction: A review of relationships with antecedents and variables. Psychological Bulletin, 64, 259-309.

Lounsbury, J. W. \& DeNeui, D. (1996). Collegiate psychological sense of community in relation to size of college/university and extroversion. Journal of Community Psychology, 24(4), 381-394.

Maxwell, W. E. (1998). Supplemental instruction, learning communities and students studying together. Community College Review, Fall Issue. [viewed 19 Mar 2001, verified 29 Jul 2003]

http: / / www.findarticles.com/cf_0/m0HCZ/2_26/53420232/p1/article.jhtml

McLellan, H. (1998). The Internet as a virtual learning community. Journal of Computing in Higher Education, 9(2), 92-112.

McMillan, D. W. (1996). Sense of community. The Journal of Community Psychology, 24(4), 315-325.

McMillan, D. W., \& Chavis, D. M. (1986). Sense of community: A definition and theory. Journal of Community Psychology, 14, 6-23.

Moore, A. B. \& Brooks, R. (2000). Learning communities and community development: Describing the process. Learning Communities: International Journal of Adult and Vocational Learning, Issue No.1(Nov), 1-15. [verified 29 Jul 2003] http:/ / www.crlra.utas.edu.au/Pages / files/journal/articles/iss1/1Moore\&B.pdf

Nonaka, I. (1991). The knowledge creating company. Harvard Business Review, 69(Nov-Dec), 96-104.

Obst, P., Zinkiewicz, L. \& Smith, S. (2002). Sense of community in Science Fiction Fandom Part 1: Understanding sense of community in an international community of interest. Journal of Community Psychology, 30(1), 87-103.

Palloff, R., \& Pratt, K. (1999). Building Learning Communities in Cyberspace. San Francisco: Josey-Bass Publishers.

Panitz, T. (1997). The Case for Student Centred Instruction Via Collaborative Learning Paradigms. [viewed 29 Nov 2001, verified 29 Jul 2003] http:/ / home.capecod.net/ tpanitz / tedsarticles/ coopbenefits.htm

Papert, S. (1990). Constructionist Learning. Cambridge: MIT Media Laboratory. 
Paulsen, M. F. (1995). Moderating educational computer conferences. In Z. L. Berge \& M. P. Collins (Eds.), Computer Mediated Communication and the Online Classroom Volume Three: Distance Learning (pp. 81-104). New Jersey: Hampton Press.

Polanyi, M. (1967). The Tacit Dimension. London: Routledge and Kegan Paul.

Puddifoot, J. E. (1996). Some initial considerations in the measurement of community identity. The Journal of Community Psychology, 24(4), 327-334.

Putnam, R. D. (2000). Bowling Alone. New York: Simon and Schuster.

Redfield, R. (1960). The Little Community and Peasant Society and Culture. Chicago: The University of Chicago Press.

Rovai, A. (2002). Development of an instrument to measure classroom community. The Internet and Higher Education, 5, 197-211.

Royal, M. A., \& Rossi, R. (1996). Individual-level correlates of sense of community: Findings from workplace and school. Journal of Community Psychology, 24(5), 395-416.

Salmon, G. (2000). E-Moderating: The key to teaching and learning online. London: Kogan Page Limited.

Sarason, S. B. (1974). The Psychological Sense of Community. San Francisco: JosseyBass Publishers.

Slavin, R. E. (1990). Cooperative Learning Theory, Research and Practice. Needham Heights, Massachusetts: Allyn and Bacon.

Sonn, C., Bishop, B. \& Drew, N. (1999). Sense of community: issues and considerations from a cross-cultural perspective. Community, Work E Family, 2(2), 205-218.

Stewart, T. A. (1997). Intellectual capital. New York: Doubleday/Currency.

Suler, J. (2000). Maximizing the Well Being of Online Groups: The Clinical Psychology of Virtual Communities. [viewed 7 May 2003, verified 29 Jul 2003] http: / / www.rider.edu/ suler/ psycyber/clinpsygrp.html

Surratt, C. G. (1998). Internet Citizens and Their Communities. New York: Nova Science Publishing inc.

Tannen, D. (1990). You just don't understand: Women and men in conversation. New York: William Morrow and Company.

Tannen, D. (1994). Talking from 9 to 5: How women's and men's conversations styles affect who gets heard, who gets credit, and what gets done at work. New York: William Morrow and Company Inc.

Tannen, D. (1995). Gender and Discourse. New York NY: Oxford University Press.

Tönnies, F. (1955). Community andAssociation (C. P. Loomis, Trans.). London: Routland \& Kegan Paul Ltd. 
Triandis, H. C. (1996). The psychological measurement of cultural systems. American Psychologist, 51(4), 407-415.

Von Krogh, G. (1998). Care in knowledge creation. California Management Review, 40(3), 133-153.

Von Krogh, G., Ichijo, K. \& Nonaka, I. (2000). Enabling Knowledge Creation. Oxford NY: Oxford University Press.

Vygotsky, L. S. (1978). Mind in society: The development of higher psychological processes (M. Cole, V. John-Steiner, S. Scribner \& E. Souberman, Trans.). Cambridge: MA: Harvard University Press.

Wenger, E. (1998). Communities of practice: Learning meaning and identity. Cambridge: Cambridge University Press.

Wenger, E., McDermott, R. \& Snyder, W. (2002). Cultivating Communities of Practice. Boston Massachusetts: Harvard Business School Press.

Wiesenfeld, E. (1996). The concept of 'We': A community social psychology myth? The Journal of Community Psychology, 24(4), 337-346.

Worsley, P. (1991). The New Modern Sociology Readings (2nd ed.). New York: Penguin Books Ltd.

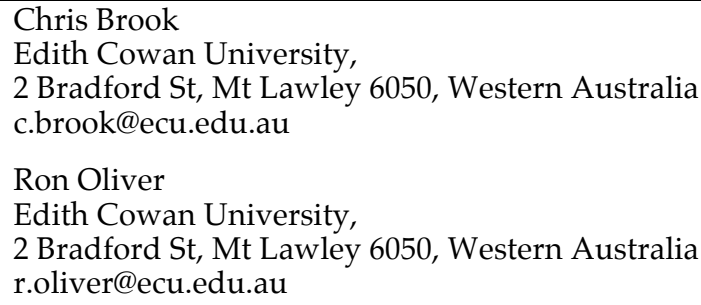

